\title{
Heavy metals pollution in soil profiles from seasonal- flooding riparian \\ wetlands in a Chinese Delta: Levels, distributions and toxic risks
}

Guangliang Zhang, Junhong Bai*, Qingqing Zhao, Jia Jia, Xiaojun Wen

\begin{abstract}
Soil profile samples were collected in seasonal-flooding riparian wetlands in the Yellow River Delta (YRD) of China in autumn and spring to investigate the levels, distributions and toxic risks of heavy metals in soil profiles. Total elemental contents of $\mathrm{Al}, \mathrm{As}, \mathrm{Cd}, \mathrm{Cr}, \mathrm{Cu}, \mathrm{Ni}, \mathrm{Pb}$ and $\mathrm{Zn}$ were determined using inductively coupled plasma atomic absorption spectrometry (ICP-AAS). Results indicated that the contents of determined heavy metals showed non-negligible depth variations (coefficient of variation $>10 \%$ ), and their distribution patterns were irregular. Compared with other heavy metals, both As and Cd presented higher enrichment factors (EF) based on the classification of EF values (moderate enrichment for As while significant enrichment for $\mathrm{Cd}$ ). Cluster analysis (CA) and principal components analysis (PCA) revealed that $\mathrm{Cr}, \mathrm{Cu}, \mathrm{Ni}$, $\mathrm{Pb}$ and $\mathrm{Zn}$ might derive from the common source, while $\mathrm{As}$ and $\mathrm{Cd}$ shared another similar source. The toxic unit (TU) values of these heavy metals did not exceed probable effect levels (PEL) except for Ni. Both As and Ni showed higher contributions to the sum of TU ( $\sum \mathrm{TUs}$ ), which indicated they were the primary concerns of heavy metals pollution. Generally, As, Cd and $\mathrm{Ni}$ should be paid more attention for wetlands managers and policy makers to avoid potential ecotoxicity in the study area. The findings of this study could contribute to the prevention and control of heavy metals pollution in estuarine wetlands.
\end{abstract}

Keywords: Heavy metals; Profile distribution; Pollution levels; Toxic units; Yellow River Delta.

\section{Introduction}

Estuarine and coastal wetlands are complex and important ecosystems, which provide multitudinous habitats for a diverse array of flora and fauna (Bai et al., 2012; Mitsch and Gosselink, 2007). Meanwhile, the fragility of these ecosystems make them more easily destructed by the anthropogenic activities in these areas.

Estuarine wetlands may act as geochemical traps for heavy metals bonded in the sediments and soils due to the complex interaction between fluvial and marine processes (Sun et al., 2015). With the rapid development of agriculture and industry, pollutants including metallic elements are continuously discharged into rivers without effective treatment, more and more intense human activities would also aggravate heavy metals pollution in these zones. Soils or sediments in 
riparian wetlands do not only act as the main precipitator for trace metals, but are also potential secondary sources of heavy metals when hydrological conditions change in these wetlands (Xie et al., 2014; Chen et al., 2016). Polluted sediments transported onto the river terrace due to flooding, contribute significant quantities of heavy metals to riparian soils (Bai et al., 2012).

The riparian zone consists of different landscape units characterized by different hydrogeomorphological site conditions, which is determined by flooding frequency and duration, distance to river channels, elevation, and water flow velocity (Graf-Rosenfellnera et al., 2016). Hydrological conditions such as intensity and duration of flooding and groundwater level, would significantly affect the migration and transformation of metals in riparian wetlands soils (Pavlović et al., 2016).

The Yellow River delta (YRD) is one of the most rapid sedimentation areas on earth, it is estimated that approximately $1.05 \times 10^{7}$ tons of sediments per year are carried and deposited in this delta (Xu et al., 2002; Zhang et al., 2016). The severe hydrological fluctuations would significantly change biogeochemical processes (e.g., heavy metals pollution) in the adjacent area. And Bai et al. (2012) has demonstrated that the flow-sediment regulation regime could contribute to some heavy metals accumulation (As and Cd) in this region. However, few study has focused on the profile distribution of heavy metals in seasonal-flooding riparian wetlands soil, and the information of seasonal dynamic changes for heavy metals pollution in needed for better understanding the ecological toxic risks caused by heavy metals. Therefore, The primary objectives of this study were: (1) to investigate the profiles distribution of heavy metals (including $\mathrm{As}, \mathrm{Cd}, \mathrm{Cr}, \mathrm{Cu}, \mathrm{Ni}, \mathrm{Pb}$ and $\mathrm{Zn}$ ) in riparian soils from seasonal-flooding wetlands of $\mathrm{YRD}$, China; (2) to assess the pollution levels based on the enrichment factor (EF) and toxic risks by toxic units (TUs); (3) to reveal the association among heavy metals using cluster analysis (CA) and principal components analysis (PCA).

\section{Materials and methods}

\section{Study area}

The study area is located in the new born wetlands of Yellow River Delta (Fig. 1), Shandong province, China. It has a warm-temperate and continental monsoon climate, with annual mean precipitation of $640 \mathrm{~mm}$ and annual mean evaporation of $1962 \mathrm{~mm}$. The annual mean air temperature is $11.9^{\circ} \mathrm{C}$, with 196 frostless days. Soil type in this region is typical Fluvisols, originating from the sediment and the parent materials of loess soil. The dominant vegetation primarily comprises Phragmites australis, Suaeda salus and Tamarix chinensis. 


\section{Soil sampling and analysis}

Soil samples were collected using a soil auger ( $4.8 \mathrm{~cm}$ diameter) from four sampling sites in autumn (November, 2007), and spring (April, 2008). In each sampling site, the top $100 \mathrm{~cm}$ soils (sectioned into 0-10, 10-20, 20-40, 40-60, 60-80, and 80-100 cm) were collected with three replicates, and three replicates were mixed uniformly into one sample in the same soil profile. All soil samples were placed in polyethylene bags and brought to the laboratory, then air dried at room temperature for three weeks. Some air-dried soils at each site in each sampling season were used for soil particle size analysis. All the other air-dried soil samples were sieved through a 2mm nylon sieve to remove coarse debris, and then ground with a pestle and mortar until all particles passed a $0.149-\mathrm{mm}$ nylon sieve for the determination of soil chemical properties. Soil bulk density cores were also correspondingly collected using a $184 \mathrm{~cm}^{3}$ cylinder from each soil layer of each soil profile, oven dried at $105^{\circ} \mathrm{C}$ for $24 \mathrm{~h}$, and weighed for the determination of bulk density (BD) and soil water content (SWC).

Soil samples were digested with an $\mathrm{HClO}_{4}-\mathrm{HNO}_{3}-\mathrm{HF}$ mixture in Teflon tubes to determine the contents of total sulfur (TS), total phosphorous (TP), $\mathrm{Al}, \mathrm{As}, \mathrm{Cd}, \mathrm{Cr}, \mathrm{Cu}, \mathrm{Ni}, \mathrm{Pb}$ and $\mathrm{Zn}$. The digested solutions of soil samples were analyzed using the inductively coupled plasma atomic absorption spectrometry (ICP-AAS). Quality assurance and quality control were assessed using duplicates, method blanks and standard reference materials (GBW07401) from the Chinese Academy of Measurement Sciences with each batch of samples( 1 blank and 1 standard for each 10 samples). The recoveries of samples spiked with standards ranged from $95 \%$ to $106 \%$. Soil organic matter(SOM) was measured using dichromate oxidation (Page et al., 1982). Soil pH and soil salt content (SSC) were determined in the supernatants of 1:5 soil and water mixtures using a Hach pH meter (Hach Company, Loveland, CO, USA) or salinity meter (VWR Scientific, West Chester, Pennsylvania, USA). Soil particle size was analyzed on a Laser Particle Size Analyzer (Microtrac Inc., USA).

\subsection{Assessment methods}

In our study, enrichment factor (EF) was selected to assess the pollution levels and the possible anthropogenic impact of each of the observed heavy metals. Aluminum (Al) was used as the reference element for geochemical normalization. $\mathrm{EF}$ is defined as $\mathrm{EF}=(\mathrm{M} / \mathrm{Al})_{\text {sample }} /(\mathrm{M} /$ Al)background (Bai et al., 2014), where $\mathrm{M}_{\text {sample }}$ and $\mathrm{M}_{\text {background }}$ are the determined contents of targeted elements (e.g., $\mathrm{As}, \mathrm{Cd}, \mathrm{Cr}, \mathrm{Cu}, \mathrm{Ni}, \mathrm{Pb}$ and $\mathrm{Zn}$ ) in soil samples and their background values, respectively; $\mathrm{Al}_{\text {sample }}$ and $\mathrm{Al}_{\text {background }}$ are the measured $\mathrm{Al}$ content in soil samples and the $\mathrm{Al}_{\text {background }}$ 
value, respectively. Pollution levels were classified into five categories based on EF values: (1) $\mathrm{EF}<2$, deficiency to minimal enrichment; (2) $\mathrm{EF}=2-5$, moderate enrichment; (3) $\mathrm{EF}=5-20$, significant enrichment; (4) $\mathrm{EF}=20-40$, very high enrichment; and (5) $\mathrm{EF}>40$, extremely high enrichment (Han et al., 2006). Background values of heavy metals were from the China National Environmental Monitoring Center (CNEMC, 1990).

Toxic units (TUs) were used to normalize the toxicities of various heavy metals to allow for the comparison of the relative effects (Bai et al, 2011). TUs are defined as the ratios of the detected contents of heavy metals to the probable effect level (PEL) values (Pedersen et al., 1998). PEL represent the thresholds of chemical contents above which adverse effects are likely to occur, the PEL values for marine and estuarine ecosystem was used in this study (Long and Mac Donald, 1998).

\subsection{Statistical analysis}

Pearson correlation analysis, descriptive statistics and principal component analysis (PCA) of soil properties were carried out in SPSS 17.0. Correlation was assumed to be statistically significant at $p<0.05$. Cluster analysis (CA) were used for source identification of heavy metals, which were performed using the software package $\mathrm{R}$ ( $\mathrm{R}$ version 3.2.4) for Windows.

\section{Results and discussion}

\subsection{Soil characteristics in the seasonal-flooding riparian wetlands}

Soil physico-chemical properties and heavy metals of all samples are summarized in Table1. Soil $\mathrm{pH}$ value ranged from 7.75 to 8.83 , indicating the weakly alkaline soil environment in the study area. Higher coefficients of variation (CV) of soil organic matter (SOM, 61.95\%), soil salt content (SSC, 42.11\%) and soil texture were observed among those determined soil properties, which implied the strong interactions of freshwater and saltwater in this estuarine area. Similarly, all heavy metals exhibited moderate variability $(10 \%<\mathrm{CV}<100 \%)(\mathrm{Hu}$ et al., 2008).

\subsection{Profile distribution of heavy metals}

Profile distribution of seven heavy metals (As, $\mathrm{Cd}, \mathrm{Cr}, \mathrm{Cu}, \mathrm{Ni}, \mathrm{Pb}$ and $\mathrm{Zn}$ ) at four sampling sites in the two seasons are shown in Figure 2. Generally, their distribution patterns are irregular in our study. Some researches pointed out that heavy metals such as $\mathrm{As}, \mathrm{Cu}, \mathrm{Pb}$ and $\mathrm{Zn}$ decreased with increasing depths in wetland ecosystems (Prusty et al., 2007; Bai et al., 2014), which might be associated with plant cycling because plant growth would lead to trace elements upwards movement through plant litters and return to surface soils (Gregorauskiene and Kadunas, 2006). However, this mechanism can not be used to explain the vertical distribution pattern in this study, 
for example, the As content in surface layer $(0-10 \mathrm{~cm})$ at site B was lower than those in sub-surface layer $(10-20 \mathrm{~cm})$ in Figure 2. The profile distribution variation of As was larger than other heavy metals (Table 1 and Figure 2). The seasonal variations in these heavy metal contents might be associated with hydrological fluctuations and plant uptake (Pavlović et al., 2016; Pandey et al., 2015; Sun et al., 2015; Bai et al., 2014).

The threshold effect levels (TELs) and probable effect levels (PELs) were developed to evaluate the ecotoxicology of heavy metals in wetland soils for marine ecosystems (Long and Mac Donald, 1998). Based on the sediment quality guidelines (SQGs) for marine ecosystem (Table 2), the contents of $\mathrm{Cd}, \mathrm{Cu}$ and $\mathrm{Pb}$ were close to the TEL threshold (Figure 2), and all samples did not exceed the TEL values for $\mathrm{Zn}$ at four sampling sites in two seasons. In addition, As and $\mathrm{Cr}$ contents in almost all samples were grouped into TEL-PEL. In this study area, Ni was the only metal which might result in toxic effects on ecosystem because some samples exceeded the PEL threshold (Figure 2), therefore, Ni was identified as heavy metals of primary concerns in the YRD. Generally, the contents of these heavy metals at sites A and B were relatively lower than those at sites $\mathrm{C}$ and D (Figure 2). On one hand, the spatial variation was ascribed to the geochemical inherent characteristics (Sun et al., 2015; Bai et al., 2014). On the other hand, sites A and B are much closer to the Yellow River, the time of duration and flooding water level varied between sites $\mathrm{A}$ and $\mathrm{B}$ and sites $\mathrm{C}$ and D. Different hydrological condition would affect soil physicochemical properties (e.g., soil salinity) and then alter the mobility of heavy metals in soil (Acosta et al., 2011).

\subsection{Enrichment factor}

Enrichment factor (EF) is an index to assess the status and degree of soil heavy metal pollution in the riverine, estuarine, and coastal environments (Ye et al., 2011). Heavy metals contents in the upstream loess were used as background values (Table 2) to calculate the enrichment levels for heavy metals in the soils. EF values less than 0.5 reflect the mobilization and loss of the measured element relative to $\mathrm{Al}$, and those values ranging from 0.5 to 1.5 indicate that the metals are entirely from crustal materials or natural weathering processes, whereas EF values higher than 1.5 imply probable anthropogenic pollution sources(Zhang and Liu, 2002; Zhang et al., 2016).

Figure 3 shows the enrichment level of seven heavy metals in riparian wetlands soils at four sites in Autumn and Spring. Cd levels in all soil layers were at the significant enrichment level in two seasons. Comparatively, almost all soil samples showed minimal enrichment levels (0.5-1.5) 
of $\mathrm{Cu}, \mathrm{Pb}$ and $\mathrm{Zn}$ in four sampling sites in the two seasons, which means no or low pollution of $\mathrm{Cu}, \mathrm{Pb}$ and $\mathrm{Zn}$ in the study area. However, As levels in almost $95 \%$ of soil samples were at a moderate enrichment level. It's worth noting that almost all $\mathrm{EF}$ values of $\mathrm{As}$ and $\mathrm{Cd}$ and more than $70 \%$ of $\mathrm{EF}$ values of $\mathrm{Cr}$ and $\mathrm{Ni}$ in the two seasons exceeded 1.5, indicating that a non-negligible portion of metals is delivered from non-crustal materials, or non-natural weathering processes, so anthropogenic sources might be an important contributor for these heavy metals (Bai et al., 2014).

\subsection{Multivariate analysis}

Multivariate analysis (e.g., Principle component analysis (PCA) and cluster analysis (CA)) were widely applied for source identification of heavy metals (Karim et al., 2014; Zhang et al., 2010; Han et al., 2006), which could provide some information about association of heavy metals. Heatmap obtained by the two-way cluster analysis classifies the variables into different clusters depending upon the resemblance among them (Pandey et al., 2015). The EF values of heavy metals were used for cluster analysis, and the results were showed in Figure 4 (soil layers at each sampling site weren't clustered in this figure to avoid disorder). For both seasons, three clusters were obtained for these heavy metals, including $\mathrm{C} 1(\mathrm{Cd}), \mathrm{C} 2(\mathrm{As})$ and $\mathrm{C} 3(\mathrm{~Pb}, \mathrm{Cu}, \mathrm{Zn}, \mathrm{Cr}$ and $\mathrm{Ni}$ ). The behavior and origin of $\mathrm{Cd}$ and As might be different from the rest of the metals (C3) in this riparian wetland, meanwhile, seasonal variation in heavy metals didn't change the cluster results, which demonstrated CA is a reliable analysis method.

The results of PCA in Table 3 showed that two principle components (PCs) explained $81.10 \%$ of total variance based on eigenvalues (eigenvalue $>1$ ). The PC1, explaining $64.32 \%$ of the total variance, was strongly and positively related to all seven metals, and correlation analysis also exhibited significant correlations between them (Table $4, p<0.05$ ). The PC2, explaining $16.79 \%$ of the total variance, showed highly positive factor loadings on As and negative correlation with $\mathrm{Cd}$. Higher loading factors of As and $\mathrm{Cd}$ in both PCs indicated distinct behavior compared with other metals. In conclusion, both the results of PCA and CA showed that $\mathrm{Cr}, \mathrm{Cu}$, $\mathrm{Ni}, \mathrm{Pb}$ and $\mathrm{Zn}$ might derive from the common source, whereas As and $\mathrm{Cd}$ might share another source in this riparian wetland of YRD. Although Bai et al. (2012) has reported that the contents of heavy metals were lower in the YRD than in most large rivers and estuaries, continuous disturbances caused by human activities and sediment movements could aggravate heavy metals pollution in coastal zones, especially in those complex hydro-geological wetlands.

\subsection{Toxic risks}

The potential acute toxicities of contaminants in soil samples can be estimated using the toxic 
unit (TU) index, the values of sum of toxic units ( $\sum$ TUs) exceed 4 means moderate toxicity to ecosystem (Pedersen et al., 1998). The $\sum$ TUs and relative contributions of seven heavy metals at each soil layer of each site are illustrated in Figure 5. Ni showed the largest contribution to the $\sum$ TUs, followed by As and $\mathrm{Cr}$, so $\mathrm{Ni}$, As and $\mathrm{Cr}$ should be paid more attention according to $\mathrm{TU}$ assessment method. Meanwhile, the values of $\sum$ TUs in site C and D were larger than sites A and B, those values which exceed 4 were only found at sites C and D (Figure 5). Figure 6 presented the $\sum$ TUs distribution more visually from site A to site D (x axis) in different soil layers (y axis) in two seasons. Generally, the toxic risks increased from sites A and B to sites C and D. For site C, the toxic values in surface soils were higher than deep soils in both sampling seasons, while TU decreased from autumn to the next spring. Comparatively, an increase in the $\Sigma$ TUs values was observed at site D . This dynamic change indicated heavy metals would be significantly migrated under seasonal flooding conditions (Pavlović et al., 2016). Almost all soil samples showed the $\sum$ TUs values less than 4, suggesting low ecotoxicity in the current YRD soils (Bai et al., 2014).

\section{Conclusions}

Results indicated that the contents of determined heavy metals showed non-negligible depth profile variations (coefficient of variation $>10 \%$ ), and the distributions patterns of them were irregular. Cluster analysis (CA) and principal components analysis (PCA) revealed that $\mathrm{Pb}, \mathrm{Cu}$ and $\mathrm{Zn}$ originated from the common source, and $\mathrm{As}$ and $\mathrm{Cd}$ shared another similar source. Generally, As, Cd and Ni should be paid more attention for wetlands managers and policy-makers to avoid potential ecotoxicity to coastal ecosystems in the Yellow River Delta based on the enrichment factors and toxic units. The contents of heavy metals in riparian wetlands showed obvious seasonal variation, this study merely considered the total contents of metals, the fractions of heavy metals need to be further studied for better understanding of metals contamination dynamics of riparian soils. Furthermore, it is necessary to recognize water-sediment relations in seasonal-flooding riparian wetlands and to deal with the heavy metal pollution issues as a whole.

\section{Acknowledgements}

This study was financially supported by the National Basic Research Program of China (no. 2013CB430406), the National Science Foundation for Innovative Research (no. 51421065), the National Natural Science Foundation (no. 51379012) and the Young Top-Notch Talent Support Program of China. The authors acknowledge all colleagues for their contributions to the fieldwork.

\section{Reference}


Acosta, J.A., Jansen, B., Kalbitz, K., Faz, A., Martínez-Martínez, S., 2011. Salinity increases mobility of heavy metals in soils, Chemosphere 85, 1318-1324.

Bai, J.H., Xiao, R., Cui, B.S., Zhang, K.J., Wang, Q.G., Liu, X.H., Gao, H.F., Huang, L.B.,2011. Assessment of heavy metal pollution in wetland soils from the young and old reclaimed regions in the Pearl River Estuary, South China. Environ. Pollut. 159, 817-824.

Bai, J.H., Xiao, R., Zhang, K.J., Gao, H.F., 2012. Arsenic and heavy metal pollution in wetland soils from tidal freshwater and salt marshes before and after the flow-sediment regulation regime in the Yellow River Delta, China. J. Hydrol. 450-451, 244-253.

Bai, J.H., Xiao, R., Zhao, Q.Q., Lu, Q.Q., Wang, J.J., Reddy, K.R., 2014. Seasonal dynamics of trace elements in tidal salt marsh soils as affected by the flow-sediment regulation regime. PLoS One 9 (9), e107738, http://dx.doi.org/10.1371/journal.pone.0107738.

Chen, H., Chen, R., Teng, Y., Wu, Y., 2016. Contamination characteristics, ecological risk and source identification of trace metals in sediments of the Le'an River (China). Ecotox. Environ. Safe. 125, 85-92.

China National Environmental Monitoring Center (CNEMC), 1990. Chinese Elemental Background Values for Soils. Chinese Environmental Science Press Beijing.

Graf-Rosenfellnera, M., Cierjacks, A., Kleinschmit, B., Lang, F., 2016. Soil formation and its implications for stabilization of soil organic matter in the riparian zone. Catena 139, 9-18.

Gregorauskiene, V., Kadunas, V., 2006. Vertical distribution patterns of trace and major elements within soil profile in Lithuania. Geol. Q. 50, 229-237.

Han, Y.M., Du, P.X., Cao, J.J., Posmentier, E.S., 2006. Multivariate analysis of heavy metal contamination in urban dusts of Xi'an, Central China. Sci. Total Environ. 355, 176-186.

Hu, W., Shao, M.A., Wang, Q.J., Fan, J., Reichardt, K., 2008. Spatial variability of soil hydraulic properties on a steep slope in the Loess Plateau of China. Sci. Agric. 65(3), 268-276.

Karim, Z., Qureshi, B.A., Mumtaz, M., Qureshi, S., 2014. Heavy metal content in urban soils as an indicator of anthropogenic and natural influences on landscape of Karachi-A multivariate spatio-temporal analysis. Ecol. Indic. 42, 20-31.

Long, E.R., Mac Donald, D.D., 1998. Recommended uses of empirically derived, sediment quality guidelines for marine and estuarine ecosystems. Hum. Ecol. Risk Assess. 4 (5), 1019-1039.

Mitsch, W.J., Gosselink, J.G., 2007. Wetlands, fourth ed. John Wiley, Inc., New York.

Page, A.L., Miller, R.H., Keeney, D.R., 1982. Methods of Soil Analysis Part 2: Chemical and 
Microbiological Properties, 2nd edn., American Society of Agronomy, and Soil Science Society of America, Madison. WI., pp. 539-579.

Pandey, M., Pandey, A.K., Mishra, A., Tripathi, B.D., 2015. Assessment of metal species in river Ganga sediment at Varanasi, India using sequential extraction procedure and SEM-EDS. Chemosphere 134, 466-474.

Pavlović, P., Mitrović, M., Đorđević, D., Sakan, S., Slobodnik, J., Liška, I., Csanyi, B., Jarić, S., Kostić, O., Pavlović, D., Marinković, N., Tubić, B., Paunović, M., 2016. Assessment of the contamination of riparian soil and vegetation by trace metals - A Danube River case study. Sci. Total Environ. 540, 396-409.

Pedersen, F., Bjùrnestad, E., Andersen, H.V., Kjøholt, J., Poll, C., 1998. Characterization of sediments from Copenhagen Harbour by use of biotests. Water Sci. Technol. 37 (6-7), 233-240.

Prusty, B., Kumar, A., Azeez, P.A., 2007. Vertical distribution of alkali and alkaline earth metals in the soil profile of a wetland-terrestrial ecosystem complex in India. Aust. J. Soil Res. 45: $533-542$.

Sun, Z.G., Mou, X.J., Tong, C., Wang, C.Y., Xie, Z.L., Song, H.L., Sun, W.G., Lv, Y.C., 2015. Spatial variations and bioaccumulation of heavy metals in intertidal zone of the Yellow River estuary, China. Catena 126, 43-52.

Xie, Z.L., Zhao, G.S., Sun, Z.G., Liu, J.Y., 2014. Comparison of arsenic and heavy metals contamination between existing wetlands and wetlands created by river diversion in the Yellow River estuary, China. Environ. Earth. Sci. 72, 1667-1681.

Xu, X.G., Guo, H.H., Chen, X.L., Lin, H.P., Du, Q.L., 2002. A multi-scale study on land use and land cover quality change: the case of the Yellow River Delta in China. Geo. J. 56(3), 177-183.

Ye, C., Li, S.Y., Zhang, Y.L., Zhang, Q.F., 2011. Assessing soil heavy metal pollution in the waterlevel-fluctuation zone of the Three Gorges Reservoir, China. J. Hazard. Mater. 191, 366-372.

Zhang, G.L., Bai, J.H., Zhao, Q.Q., Lu, Q.Q., Jia, J., Wen, X.J., 2016. Heavy metals in wetland soils along a wetland-forming chronosequence in the Yellow River Delta of China: Levels, sources and toxic risks, Ecol. Indic. 69: 331-339.

Zhang, H.G., Cui, B.S., Xiao, R., Zhao, H., 2010. Heavy metals in water, soils and plants in riparian wetlands in the Pearl River Estuary, South China. Procedia Environ. Sci. 2, 1344-1354. 
Zhang, J., Liu, C.L., 2002. Riverine composition and estuarine geochemistry of particulate metals in China-weathering features, anthropogenic impact and chemical fluxes. Estuar. Coast. Shelf Sci. 54 (6), 1051-1070. 
Table1 Descriptive statistics of soil properties and heavy metals( $\mathrm{n}=4$ sites $\times 6$ profile layers $\times 2$ seasons $=48)$.

\begin{tabular}{|c|c|c|c|c|c|c|c|c|}
\hline & Variables & Minimum & $\begin{array}{l}\text { Maximu } \\
\mathrm{m}\end{array}$ & $\begin{array}{c}\text { Averag } \\
\text { e }\end{array}$ & $\begin{array}{l}\text { Standard } \\
\text { error }\end{array}$ & $\begin{array}{c}\text { Coefficient } \\
\text { of } \\
\text { variation( }(\%)\end{array}$ & Skewness & Kurtosis \\
\hline & $\begin{array}{c}\mathrm{SWC}(\mathrm{g} / \\
\mathrm{g})\end{array}$ & 0.2 & 0.32 & 0.243 & 0.02771 & $\begin{array}{c}11.4032921 \\
8\end{array}$ & 0.735 & 0.334 \\
\hline & $\begin{array}{c}\mathrm{BD}(\mathrm{g} / \\
\left.\mathrm{cm}^{3}\right)\end{array}$ & 1.32 & 1.93 & 1.6509 & 0.16117 & $\begin{array}{c}9.76255375 \\
9\end{array}$ & -0.014 & -1.253 \\
\hline & $\begin{array}{l}\mathrm{SOM}(\mathrm{g} / \\
\mathrm{kg})\end{array}$ & 0.96 & 12.88 & 3.779 & 2.34105 & $\begin{array}{c}61.9489282 \\
9\end{array}$ & 1.912 & 4.791 \\
\hline & $\operatorname{SSC}(\%)$ & 0.5 & 3.1 & 1.3271 & 0.55878 & $\begin{array}{c}42.1053424 \\
8\end{array}$ & 1.104 & 1.208 \\
\hline & $\begin{array}{l}\mathrm{TP}(\mathrm{mg} / \\
\mathrm{kg})\end{array}$ & 496.67 & 767.58 & 631.81 & 49.9779 & $\begin{array}{c}7.91027365 \\
8\end{array}$ & -0.387 & 1.233 \\
\hline \multirow[t]{8}{*}{$\begin{array}{c}\text { Soil } \\
\text { property }\end{array}$} & $\begin{array}{l}\mathrm{TS}(\mathrm{mg} / \\
\mathrm{kg})\end{array}$ & 276.68 & 1168.74 & $\begin{array}{c}497.40 \\
02\end{array}$ & 155.68198 & 31.299139 & 1.985 & 6.325 \\
\hline & $\mathrm{pH}$ & 7.75 & 8.83 & 8.3138 & 0.31295 & 3.76422334 & 0.064 & -1.103 \\
\hline & Sand(\%) & 28.35 & 100 & $\begin{array}{c}78.787 \\
3\end{array}$ & 18.55738 & $\begin{array}{c}23.5537707 \\
2\end{array}$ & -0.64 & -0.148 \\
\hline & Silt(\%) & 0 & 63.06 & $\begin{array}{c}19.825 \\
8\end{array}$ & 16.67148 & $\begin{array}{c}84.0898223 \\
5\end{array}$ & 0.463 & -0.54 \\
\hline & Clay(\%) & 0 & 10.52 & 1.3869 & 2.34394 & $\begin{array}{c}169.005696 \\
2\end{array}$ & 2.327 & 5.65 \\
\hline & $\begin{array}{l}\mathrm{Al}(\mathrm{mg} / \\
\mathrm{kg})\end{array}$ & 33774.12 & 82690.32 & $\begin{array}{c}56436 . \\
0663\end{array}$ & 11309.35429 & $\begin{array}{c}20.0392320 \\
6\end{array}$ & 0.199 & -0.282 \\
\hline & $\begin{array}{l}\mathrm{As}(\mathrm{mg} / \\
\mathrm{kg})\end{array}$ & 3.4 & 40.9 & $\begin{array}{c}25.316 \\
4\end{array}$ & 8.21262 & $\begin{array}{c}32.4399203 \\
7\end{array}$ & -0.432 & -0.089 \\
\hline & $\begin{array}{c}\mathrm{Cd}(\mathrm{mg} / \\
\mathrm{kg})\end{array}$ & 0.43 & 1.03 & 0.7061 & 0.13309 & $\begin{array}{c}18.8486050 \\
1\end{array}$ & 0.184 & -0.232 \\
\hline \multirow[t]{5}{*}{$\begin{array}{l}\text { Heavy } \\
\text { metals }\end{array}$} & $\begin{array}{l}\mathrm{Cr}(\mathrm{mg} / \\
\mathrm{kg})\end{array}$ & 84 & 142.1 & $\begin{array}{c}108.85 \\
24\end{array}$ & 13.76464 & $\begin{array}{c}12.6452333 \\
6\end{array}$ & 0.535 & -0.546 \\
\hline & $\begin{array}{c}\mathrm{Cu}(\mathrm{mg} / \\
\mathrm{kg})\end{array}$ & 13.9 & 43.1 & 23.319 & 6.55313 & $\begin{array}{c}28.1021055 \\
8\end{array}$ & 1.006 & 1.199 \\
\hline & $\begin{array}{l}\mathrm{Ni}(\mathrm{mg} / \\
\mathrm{kg})\end{array}$ & 33.1 & 74.32 & $\begin{array}{c}44.828 \\
8\end{array}$ & 8.91914 & $\begin{array}{c}19.8960043 \\
5\end{array}$ & 1.08 & 1.313 \\
\hline & $\begin{array}{l}\mathrm{Pb}(\mathrm{mg} / \\
\mathrm{kg})\end{array}$ & 15.2 & 36.98 & $\begin{array}{c}24.519 \\
8\end{array}$ & 5.36962 & $\begin{array}{c}21.8991182 \\
6\end{array}$ & 0.432 & -0.826 \\
\hline & $\begin{array}{c}\mathrm{Zn}(\mathrm{mg} / \\
\mathrm{kg})\end{array}$ & 46.86 & 117 & $\begin{array}{c}70.773 \\
7\end{array}$ & 15.24306 & $\begin{array}{c}21.5377463 \\
7\end{array}$ & 1.076 & 1.998 \\
\hline
\end{tabular}

Table2 The sediment quality guidelines (SQGs) for marine ecosystem and background values of heavy 
metals in YRD.

\begin{tabular}{|c|c|c|c|c|c|c|c|c|c|}
\hline & & $\begin{array}{c}\mathrm{Al} \\
(\mathrm{mg} / \\
\mathrm{kg})\end{array}$ & $\begin{array}{c}\text { As } \\
(\mathrm{mg} / \\
\mathrm{kg})\end{array}$ & $\begin{array}{c}\mathrm{Cd} \\
(\mathrm{mg} / \\
\mathrm{kg})\end{array}$ & $\begin{array}{c}\mathrm{Cr} \\
(\mathrm{mg} / \\
\mathrm{kg})\end{array}$ & $\begin{array}{c}\mathrm{Cu} \\
(\mathrm{mg} / \\
\mathrm{kg})\end{array}$ & $\begin{array}{c}\mathrm{Ni} \\
(\mathrm{mg} / \\
\mathrm{kg})\end{array}$ & $\begin{array}{c}\mathrm{Pb} \\
(\mathrm{mg} / \\
\mathrm{kg})\end{array}$ & $\begin{array}{c}\mathrm{Zn} \\
(\mathrm{mg} / \\
\mathrm{kg})\end{array}$ \\
\hline \multirow[t]{2}{*}{$\mathrm{SQGs}^{\mathrm{a}}$} & TEL & - & 7.2 & 0.68 & 52.3 & 18.7 & 15.9 & 30.2 & 124.0 \\
\hline & PEL & - & 41.6 & 4.2 & 160.4 & 108.2 & 42.8 & 112.2 & 271.0 \\
\hline $\begin{array}{c}\text { Background } \\
\text { value }^{b}\end{array}$ & & 62700 & 10.7 & 0.095 & 59.0 & 21.1 & 27.6 & 21.6 & 64.5 \\
\hline
\end{tabular}

a SQGs: sediment quality guidelines for marine ecosystem; TEL: threshold effect level; PEL: probable effect level; ERL: effects range low (Long and MacDonald, 1998).

b Background values in the Yellow River Delta. (China National Environmental Monitoring Center 1990).

Table 3 Results of principle component analysis of heavy metals for two seasons in study area. Factor loadings exceeding 0.5 are shown in bold.

\begin{tabular}{|c|c|c|c|c|c|c|}
\hline \multirow[t]{2}{*}{ Components } & \multicolumn{3}{|c|}{ Total variance explained } & \multirow[t]{2}{*}{ Heavy metals } & \multicolumn{2}{|c|}{ Component matrixes } \\
\hline & Initial Eigenvalues & $\%$ of variance & Cumulative $\%$ & & $\mathrm{PC} 1$ & PC2 \\
\hline 1 & 4.502 & 64.315 & 64.315 & As & 0.539 & 0.702 \\
\hline 2 & 1.175 & 16.788 & 81.102 & $\mathrm{Cd}$ & 0.710 & -0.519 \\
\hline 3 & 0.452 & 6.455 & 87.558 & $\mathrm{Cr}$ & 0.847 & 0.021 \\
\hline 4 & 0.413 & 5.902 & 93.460 & $\mathrm{Cu}$ & 0.914 & -0.281 \\
\hline 5 & 0.316 & 4.511 & 97.971 & $\mathrm{Ni}$ & 0.825 & 0.370 \\
\hline 6 & 0.104 & 1.490 & 99.460 & $\mathrm{~Pb}$ & 0.854 & 0.268 \\
\hline 7 & 0.038 & 0.540 & 100.000 & $\mathrm{Zn}$ & 0.863 & -0.353 \\
\hline
\end{tabular}


Table 4 Correlation matrix among heavy metal contents of the studied area in Autumn and Spring.

\begin{tabular}{cccccccc} 
& $\mathrm{As}$ & $\mathrm{Cd}$ & $\mathrm{Cr}$ & $\mathrm{Cu}$ & $\mathrm{Ni}$ & $\mathrm{Pb}$ & $\mathrm{Zn}$ \\
\hline Autumn & & & & & & & \\
$\mathrm{As}$ & 1 & $0.573^{* *}$ & $0.605^{* *}$ & $0.576^{* *}$ & $0.697^{* *}$ & $0.643^{* *}$ & $0.541^{* *}$ \\
$\mathrm{Cd}$ & $0.573^{* *}$ & 1 & $0.626^{* *}$ & $0.753^{* *}$ & $0.767^{* *}$ & $0.841^{* *}$ & $0.622^{* *}$ \\
$\mathrm{Cr}$ & $0.605^{* *}$ & $0.626^{* *}$ & 1 & $0.629^{* *}$ & $0.872^{* *}$ & $0.569^{* *}$ & $0.638^{* *}$ \\
$\mathrm{Cu}$ & $0.576^{* *}$ & $0.753^{* *}$ & $0.629^{* *}$ & 1 & $0.823^{* *}$ & $0.849^{* *}$ & $0.937^{* *}$ \\
$\mathrm{Ni}$ & $0.697^{* *}$ & $0.767^{* *}$ & $0.872^{* *}$ & $0.823^{* *}$ & 1 & $0.761^{* *}$ & $0.793^{* *}$ \\
$\mathrm{~Pb}$ & $0.643^{* *}$ & $0.841^{* *}$ & $0.569^{* *}$ & $0.849^{* *}$ & $0.761^{* *}$ & 1 & $0.707^{* *}$ \\
$\mathrm{Zn}$ & $0.541^{* *}$ & $0.622^{* *}$ & $0.638^{* *}$ & $0.937^{* *}$ & $0.793^{* *}$ & $0.707^{* *}$ & 1
\end{tabular}

$\begin{array}{cccccccc}\text { Spring } & & & & & & & \\ \mathrm{As} & 1 & -0.419^{*} & 0.221 & -0.068 & 0.444^{*} & 0.503^{*} & -0.162 \\ \mathrm{Cd} & -0.419^{*} & 1 & 0.501^{*} & 0.798^{* *} & 0.217 & 0.308 & 0.756^{* *} \\ \mathrm{Cr} & 0.221 & 0.501^{*} & 1 & 0.741^{* *} & 0.733^{* *} & 0.675^{* *} & 0.766^{* *} \\ \mathrm{Cu} & -0.068 & 0.798^{* *} & 0.741^{* *} & 1 & 0.514^{*} & 0.651^{* *} & 0.934^{* *} \\ \mathrm{Ni} & 0.444^{*} & 0.217 & 0.733^{* *} & 0.514^{*} & 1 & 0.846^{* *} & 0.482^{*} \\ \mathrm{~Pb} & 0.503^{*} & 0.308 & 0.675^{* *} & 0.651^{* *} & 0.846^{* *} & 1 & 0.535^{* *} \\ \mathrm{Zn} & -0.162 & 0.756^{* *} & 0.766^{* *} & 0.934^{* *} & 0.482^{*} & 0.535^{* *} & 1\end{array}$

* Represents significant correlation at the level of $p<0.05$.

** Represents significant correlation at the level of $p<0.01$. Figure caption

Figure 1. Location map of the study area and sampling sites. The distances for site A, B, C and D from the river south bank were $0 \mathrm{~m}, 50 \mathrm{~m}, 250 \mathrm{~m}$ and $350 \mathrm{~m}$, respectively. The vegetation types for site A, B, C and D were freshwater Phragmites australis, Tamarix chinensis-Suaeda salus, Suaeda salus and saltwater Phragmites australis, respectively. 
Figure 2. Profile distribution of seven heavy metals ( $\mathrm{As}, \mathrm{Cd}, \mathrm{Cr}, \mathrm{Cu}, \mathrm{Ni}, \mathrm{Pb}$ and $\mathrm{Zn}$ ) in four sites of two seasons.

Figure 3. Enrichment factors of seven heavy metals in riparian wetlands soils at four sites in Autumn and Spring.

Figure 4. Results of cluster analysis for seven metal species ( $\mathrm{As}, \mathrm{Cd}, \mathrm{Cr}, \mathrm{Cu}, \mathrm{Ni}, \mathrm{Pb}, \mathrm{Zn}$ ) in autumn and spring. EF in the row is the enrichment factor, 0-10, 10-20, 20-40, 40-60, 60-80, 80-100 represent the soil profile layers.

Figure 5. The $\sum$ TUs and relative contributions of seven heavy metals at each soil layer of each site.

Figure 6. Distribution of the sum of TUs ( $\sum$ TUs), $\mathrm{x}$ axis is the distance from the river south bank (m), y axis is soil depth (cm). Gridding method is the Inverse Distance to a Power.

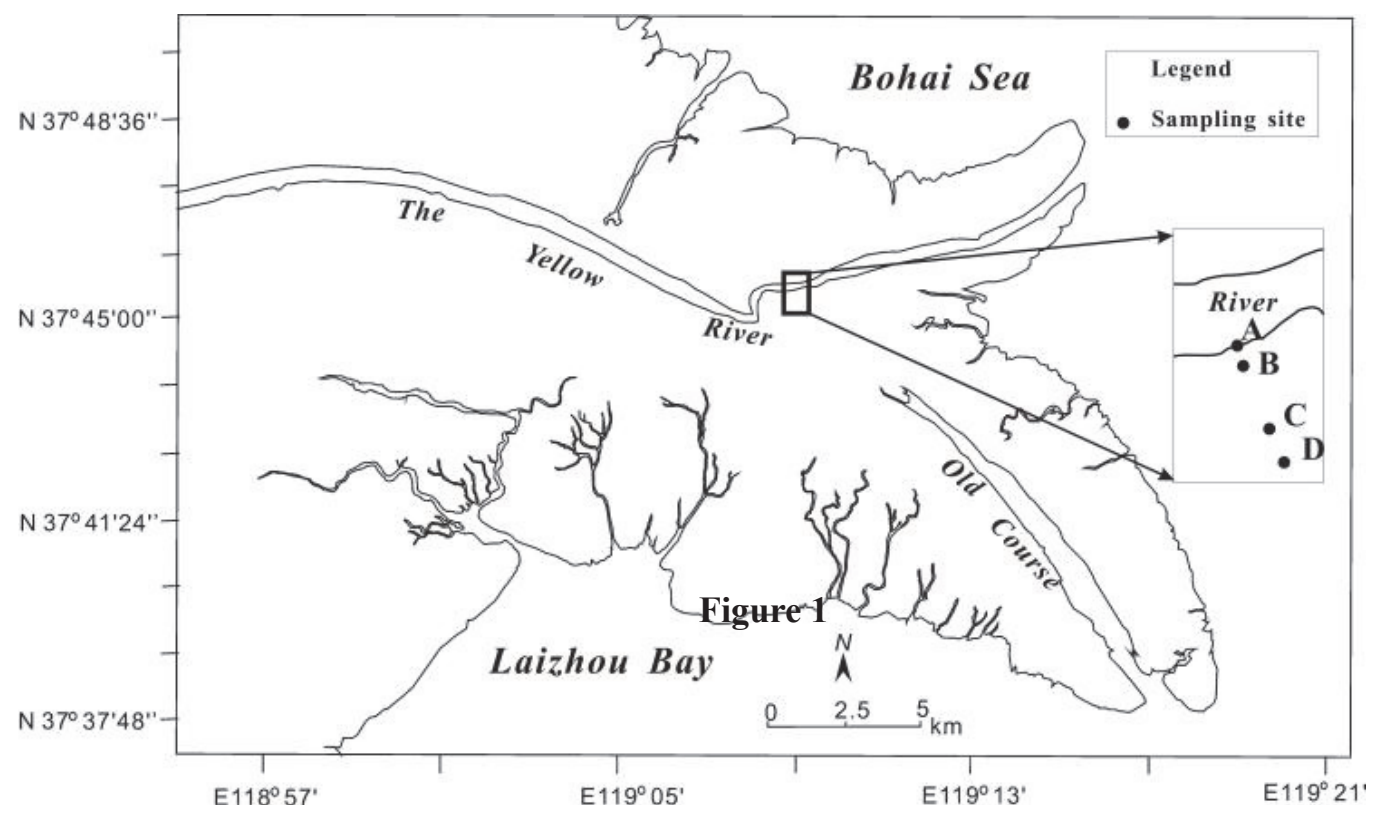



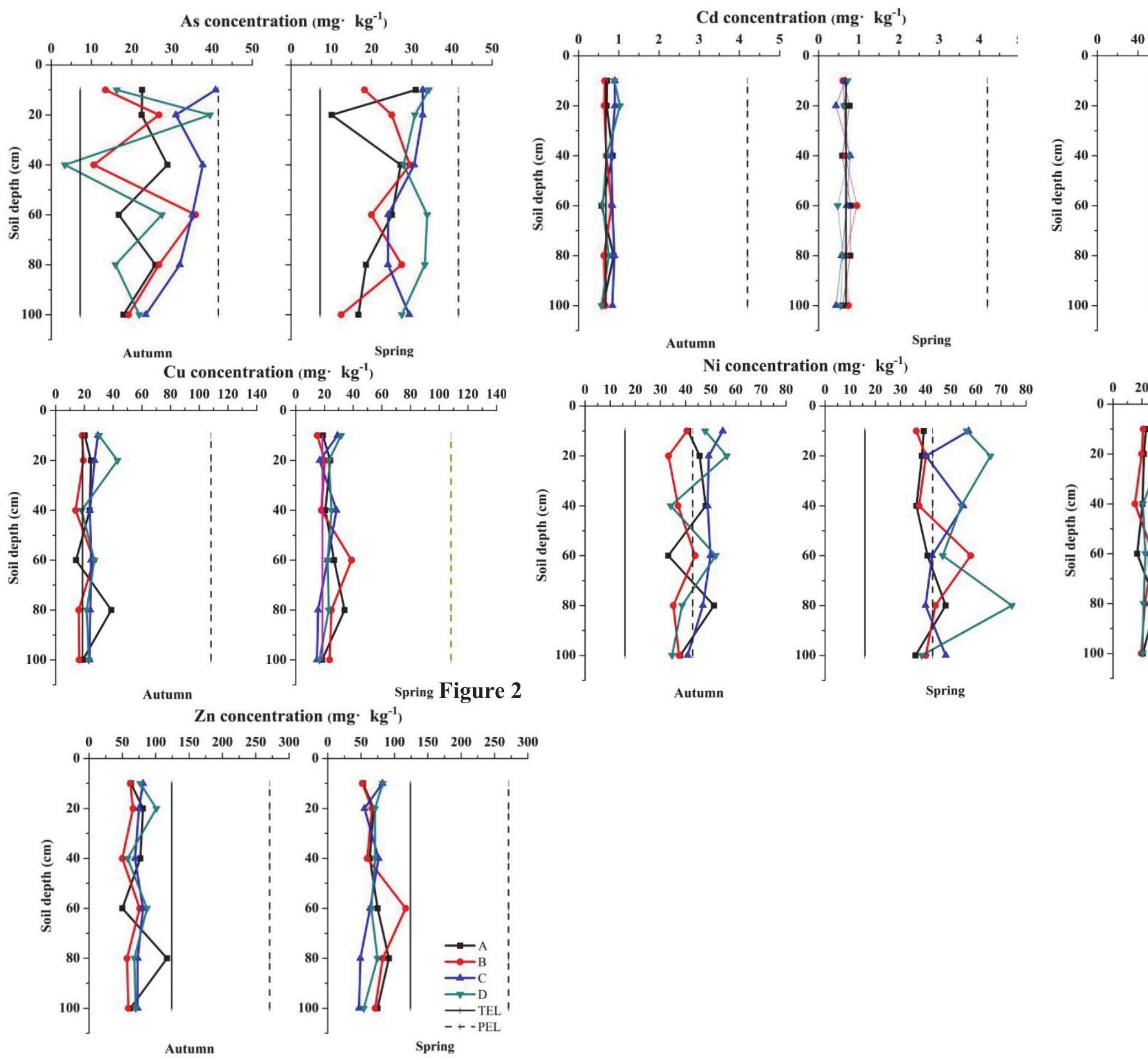

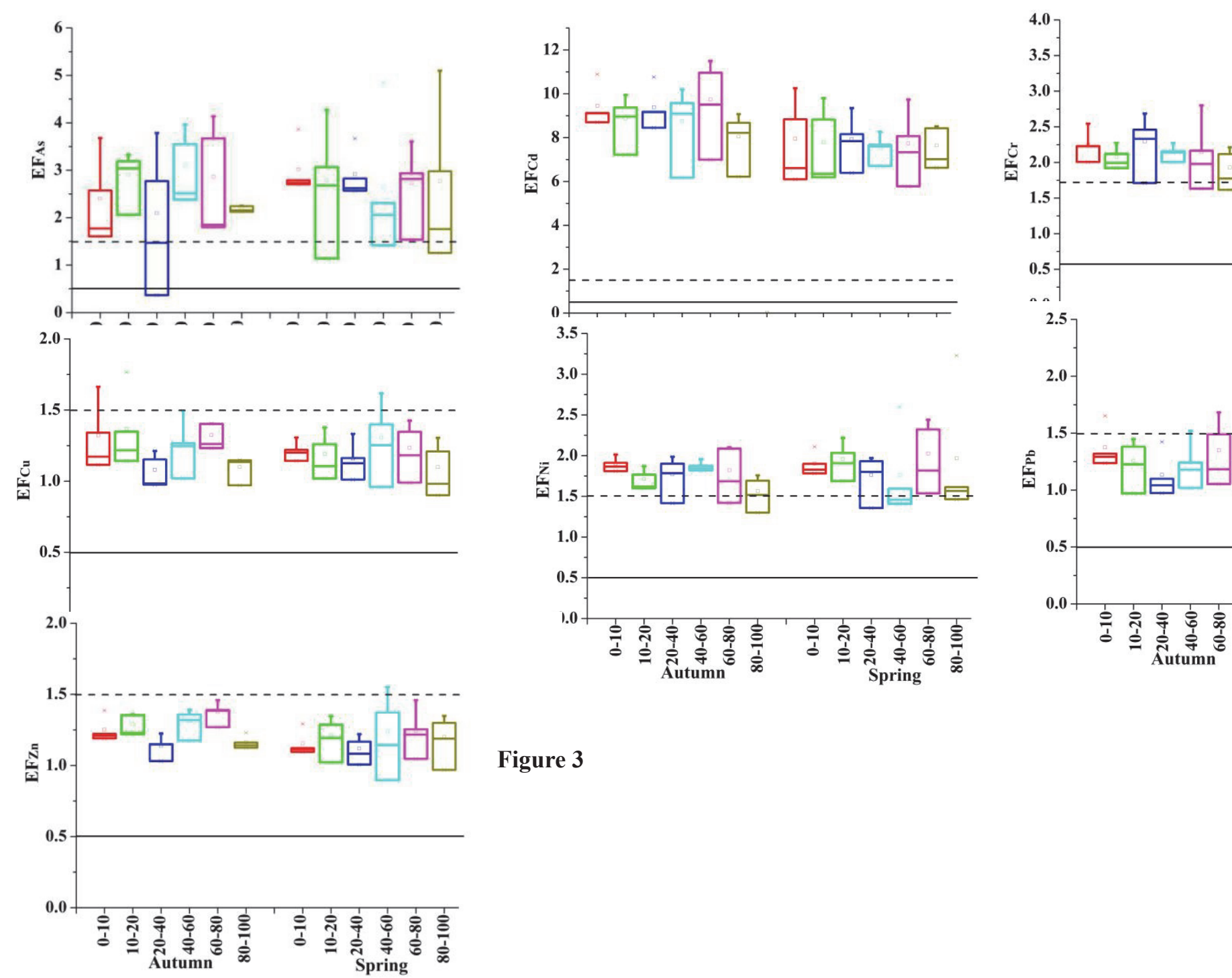

Figure 3 


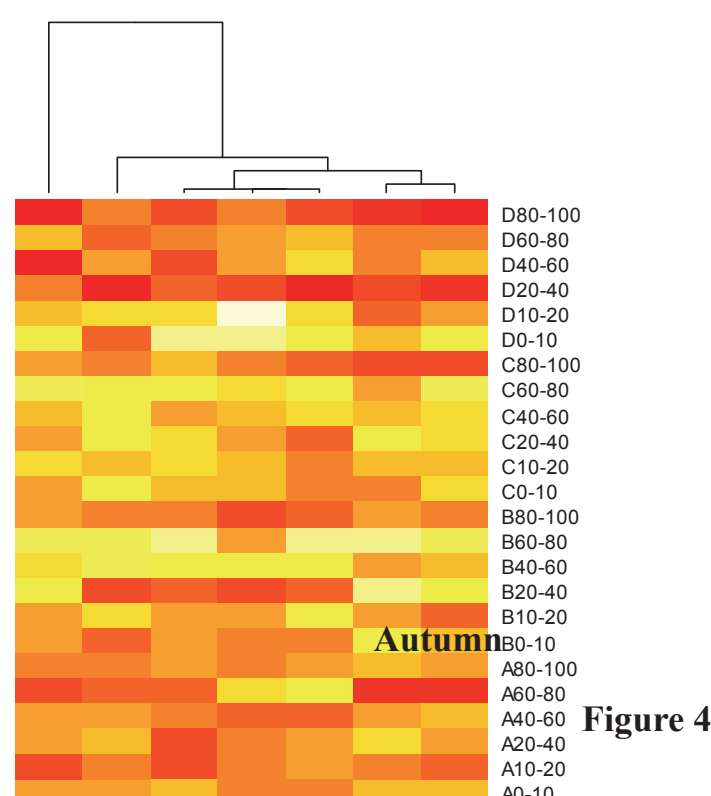

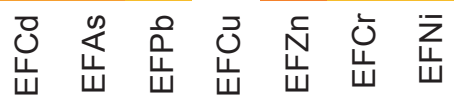

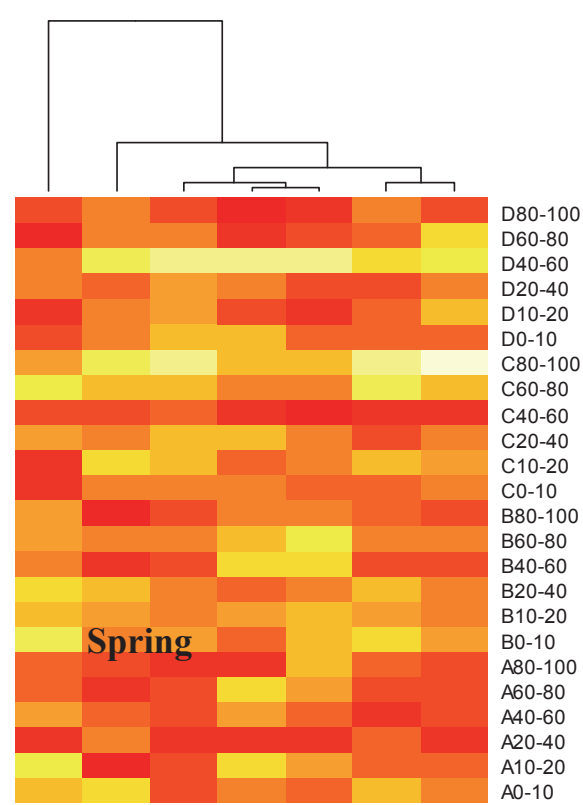

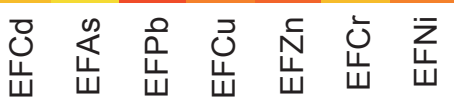

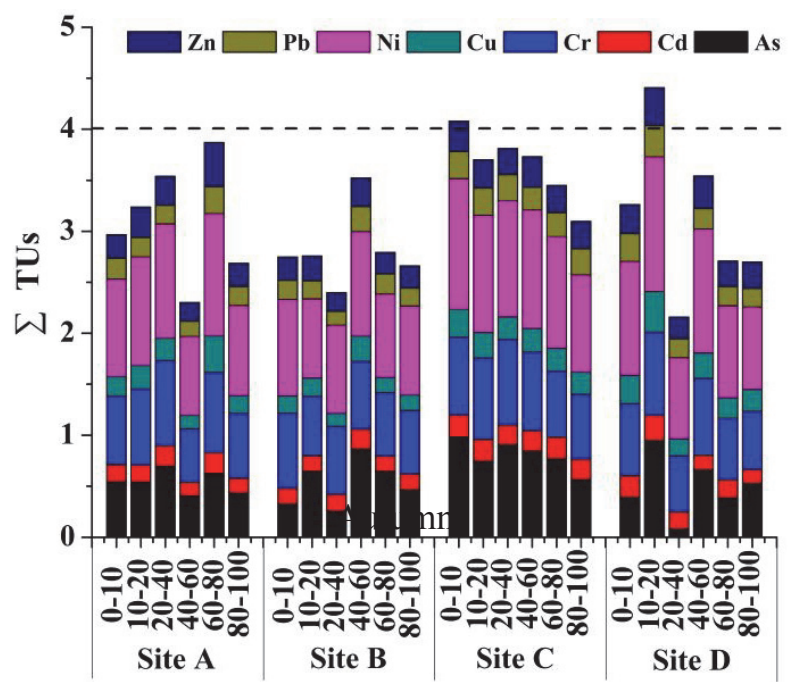



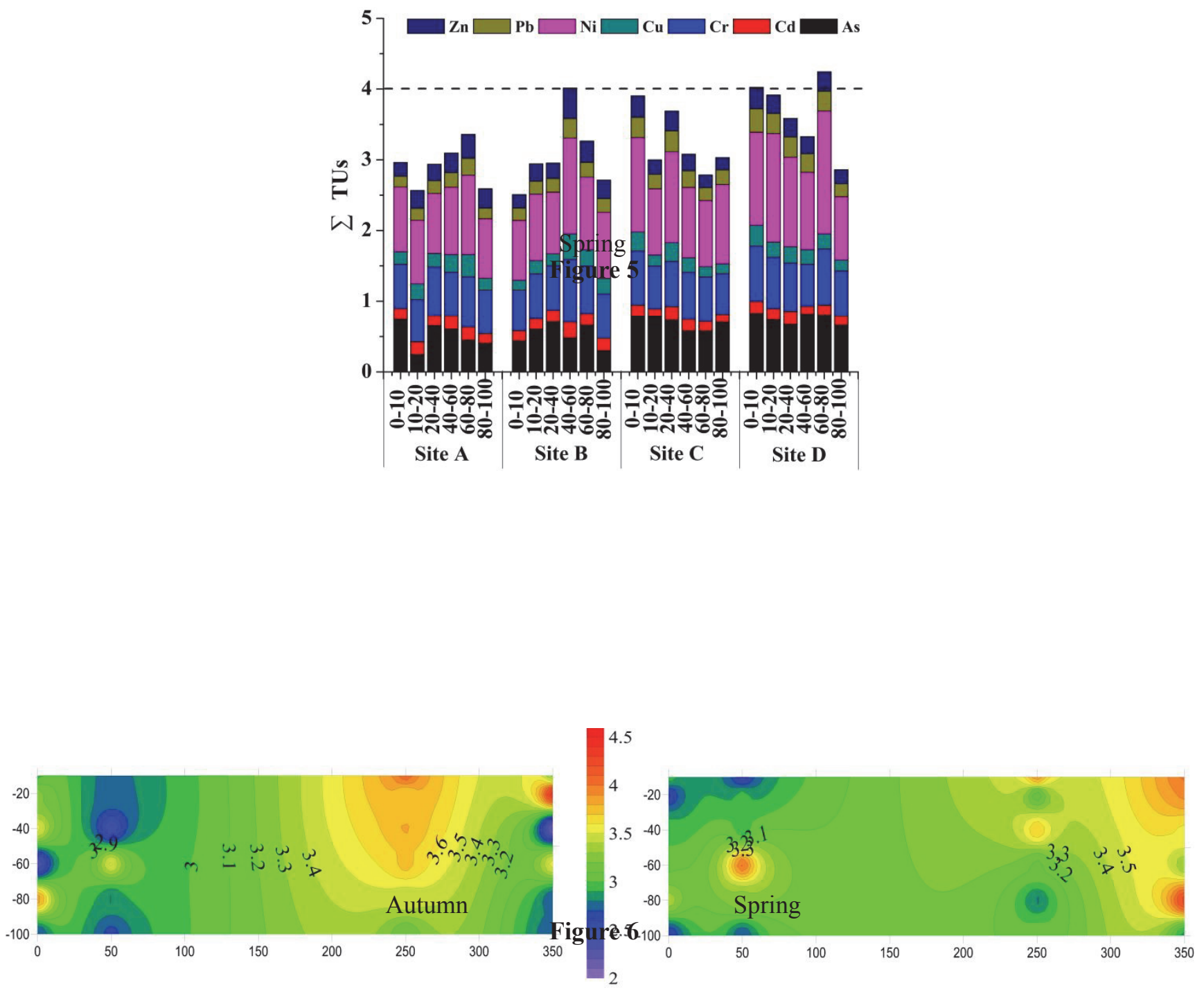